\title{
ECONOMY
}

\section{VENTURE FINANCING OF INNOVATIVE PROCESSES IN AN AGRICULTURE OF UKRAINE}

\author{
Ilona Dumanska, Ph.D., Associated Professor \\ Ukraine, Khmelnitsky, Khmelnitsky National University \\ DOI: https://doi.org/ 10.31435/rsglobal_ws/30092018/6137
}

\section{ARTICLE INFO}

Received: 06 July 2018

Accepted: 28 September 2018

Published: 30 September 2018

\section{KEYWORDS}

venture financing,

credit, investor,

innovation,

agriculture.

\begin{abstract}
The article reveals the peculiarities of ventures investigated the sources of their funding. The problems of venture financing innovation enterprises of the agricultural sector. The problems and prospects of development of venture investment in Ukraine. Found that in Ukraine is a source of venture capital organizations, large companies and commercial banks. Today, almost every company has its own venture capital fund that invests in innovative businesses related fields. Unlike the developed foreign countries in Ukraine basic research in the agricultural sector financed only by the state. This fact provokes the creation of favorable conditions for attracting private and foreign investments for the development of research and innovation in agriculture.
\end{abstract}

Citation: Ilona Dumanska. (2018) Venture Financing of Innovative Processes in an Agriculture of Ukraine. World Science. 9(37). doi: 10.31435/rsglobal_ws/30092018/6137

Copyright: (C) 2018 Ilona Dumanska. This is an open-access article distributed under the terms of the Creative Commons Attribution License (CC BY). The use, distribution or reproduction in other forums is permitted, provided the original author(s) or licensor are credited and that the original publication in this journal is cited, in accordance with accepted academic practice. No use, distribution or reproduction is permitted which does not comply with these terms.

Introduction. World experience of venture financing in agriculture shows that venture capital is not the last place in the economy of developed countries. In Europe, where there are all favorable natural conditions for conducting agricultural activities carried out, although not in a significant amount of this venture capital management areas. Considerable interest of Russian investors was paid to agriculture and amounted to almost $2 \%$ of the total investment.

This experience of financing can be considered not very significant, but as Europe, Russia, and Ukraine has the opportunity to become the origins of a new, albeit small investigated alternative sources of financing innovation in agriculture.

The main objective of the study is found necessary, and this new alternative method of financing agribusiness as venture capital, which will orient the economy towards a promising future development. To achieve this goal used methods of analysis and synthesis.

Research results. Under the conditions of reforming Ukraine's economy transition to innovation model of development means, above all, the search for new sources of funding to enhance innovation. Venture capital was so organically necessary element of aggregate economic mechanism to implement innovations at critical stages of their development and commercialization, where other mechanisms fail.

The need for risky form of financing due to the complexities of scientific advances in the production of agricultural enterprises, mass emergence of the research enterprise and its high demand for capital, its inability to meet traditional lending institutions.

The most common form is attracting investment loans from commercial banks and other financial investors, and the simplest use of economic cooperation agreements between the production 
activities of agricultural producers who strapped for cash, and now that is financially stable and jointly financed production costs.

Agricultural producers can receive credits under bilateral agreements with foreign financial investors. According to sources of financing the largest share of investments in fixed capital 1,120,200,000. UAH., Or 47.5\% covered by bank loans and other loans (January-September 2017 $41.0 \%$ ). For the own funds of enterprises and organizations utilized $37.6 \%$ of total investment, which is 3.9 percentage points more than in the corresponding period in 2017 The share of foreign investors during this period decreased by 2.2 percentage points and amounted to $0.9 \%$. At the expense of state and local budgets mastered 2.8\% of investments in fixed assets (in January-September $2017-1.8 \%$ ) [8].

The development of venture capital in modern conditions in the agricultural sector is limited. This is due to a number of objective reasons. First, there is no economic interest of the majority of agricultural enterprises in the implementation of innovative development, innovation of high technical and economic level that forms the low demand for such innovations; Secondly, underdeveloped securities market and thirdly, weak competition in the domestic market of scientific and technical products [3].

Market scientific and technical production in our country specific. There is a huge potential demand for improving existing processes, in particular the development of direct scientific and technical level. At the same time demand for revolutionary innovations really new, innovative technology is low. Market these products we almost absent, as most agricultural enterprises unable to radically change the existing technology.

Today interested in the commercial implementation of the latest developments are only foreign companies that are actively seeking to market intelligent Ukrainian products.

But despite all the obstacles, venture capital will facilitate the development and implementation of innovative projects in agriculture, because the features of this type of activity is that the funds are provided under long-term project with no guarantees newly established or small businesses and long term, and investors active involved in managing venture enterprise, thus reducing the risk and increasing the rate of return on investment [2].

Thus, we note that venture capital is one of the cheapest sources of potential funding innovation for the agricultural enterprises, as it enables the company to fully immerse themselves in self and not be distracted by debt repayment interest.

Today very popular in the EU trusts acquire venture designed to accumulate savings of individual and institutional investors.

Dividends paid to venture capital trusts, exchange rate difference between the purchase price and the sale of corporate securities is not taxable, and income tax paid by the trust venture, decreased by $20 \%$. However, to protect the rights of investors, venture capital trusts are subject to strict government regulation [1].

Technological Innovation and invention management is transferred to the practical level to improve the economic conditions of domestic enterprises and create added value. Innovation is an important component of competitiveness, the country's capacity.

The following scheme of relations that arise in complex financing innovation process in the subject of agriculture in Fig. 1. 


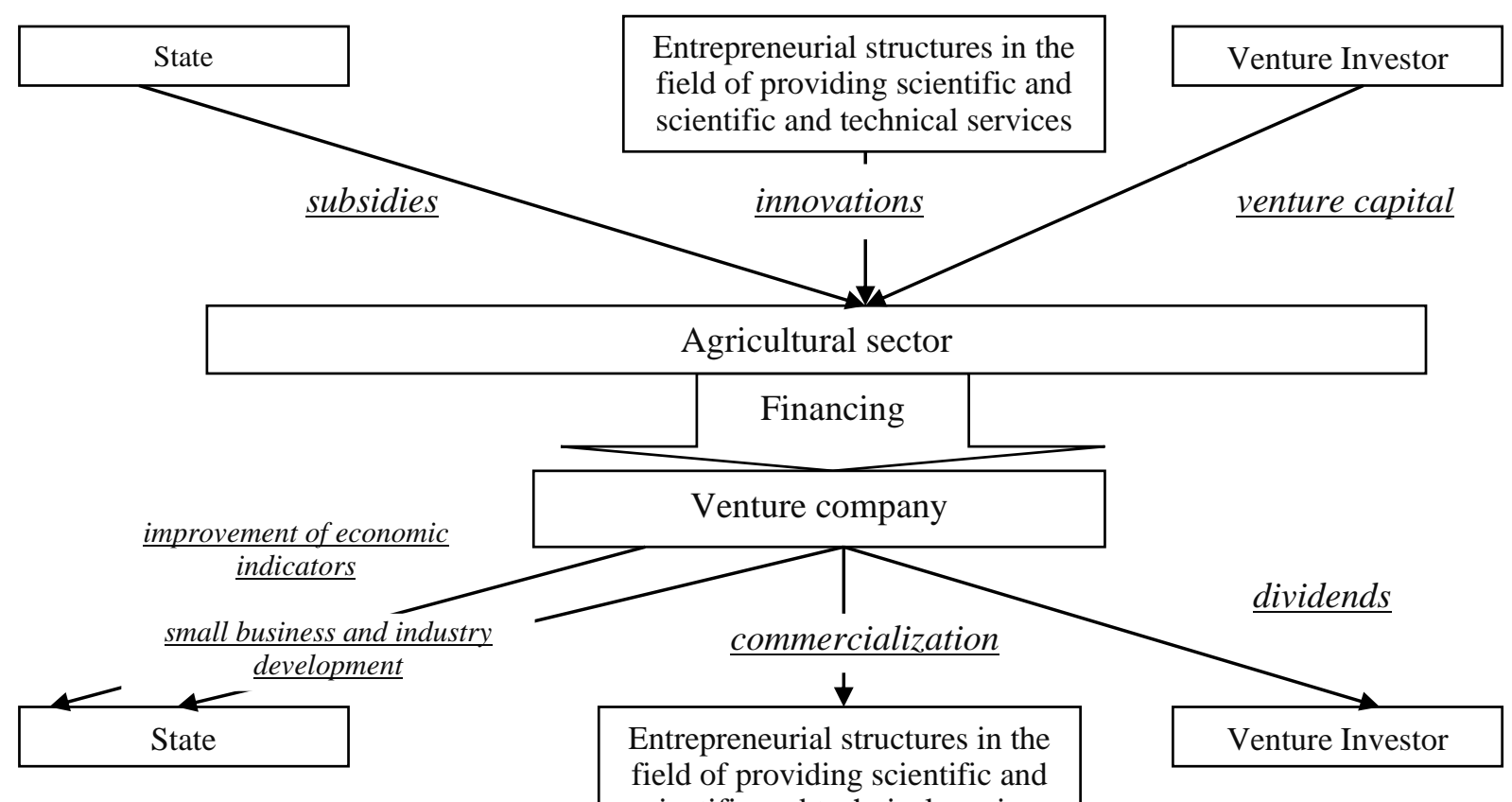

Fig. 1 Structure of venture financing innovation in the agricultural sector of Ukraine [3]

From Fig. 1. it is obvious that the use of this funding mechanism, all aspects of the relationship desired results. In particular, the state costs by making subsidies today, in the future, namely after the effective and targeted use of funds will expand small businesses, particularly in agriculture; Venture investors increase their capitalization shares and accordingly its profits; the enterprise improving their financial and expansion of production activities [7].

Through subsidies State controls the activities of agricultural enterprises, such as the targeted use them, and venture investors investing in such an enterprise reduce their risks. [6]

According to the Law of Ukraine «On State Support of Agriculture of Ukraine» envisages providing insurance and credit subsidies and budgetary subsidies [4]. It is necessary to clarify that credit subsidies to borrowers who were declared bankrupt in respect of which filed for bankruptcy or who are under liquidation. Budget subsidy unlike credit insurance and subsidies given to maintain the level of effective demand of Ukrainian consumers of animal products and to prevent loss of Ukrainian producers of such products.

In general, government intervention in agricultural markets may be through product or market agricultural resources. In other words, there are alternatives to government support, even with a deficit of the state budget, including the support prices for agricultural products, or subsidize production resources for it.

Subsidies resources for agricultural enterprises is more beneficial than keeping the price of its products, as it enables companies to reduce manufacturing costs, in accordance improved efficiency in general economic and efficient use of production resources particularly in terms of increasing production volumes.

Thus, budgetary investment allocations can be implemented partially or fully state to implement major capital-intensive projects in the development of agriculture. The main forms of investment in the agricultural sector of Ukraine are joint ventures; concluding licensing agreements science and technology centers, technology parks, techno, business incubators with domestic enterprises (venture capital companies), under which the latter acquired the right to use the new technology of production of goods; acquisitions of domestic enterprises (venture capital) [5].

Conclusions. Thus, venture capital aims to provide every Saturday innovation not only necessary financial resources, but also the support of experienced managers. The advantage of choosing an innovative design for a venture investor may be state support for agriculture in the form of grants to help divide the responsibility and risk for this project.

We therefore propose to the financing of innovations in agriculture sector involve both public and private sources of funding that are needed to stabilize production and further effective development of the agricultural sector on the basis of public-private partnership. 


\section{REFERENCES}

1. Ammos. Raise Venture / A. Ammos [Electronic resource]. - Access: http://opec.demo.metric.ru/

2. Arhiyereyev C. Role of state support of venture capital to increase production of high-tech and innovative $\begin{array}{lllll}\text { products } / & \text { C. Arhiyereyev O. Popadynets [Electronic resource]. - Access: }\end{array}$ http://old.niss.gov.ua/Monitor/May08/08.htm.

3. Dovgalyuk V. New forms of financing development and innovation in agriculture / V. Dovgalyuk // Journal of Zhitomir State Technological University. - 2012. - №2. - S. 297-299.

4. The Law of Ukraine «On State Support of Agriculture of Ukraine» dated 22.12.2011 g., Number 4216-VI: [Electronic resource]. - Access: www.rada.gov.ua.

5. Levchenko N. Forms and methods of state support of innovative development of agriculture / N. Levchenko [Electronic resource]. - Access: http://www.kbuapa.kharkov.ua/e-book/ apdu / 2010-2 / doc / 2 / 03.pdf.

6. Sirenko N. Management strategy of innovative development of agrarian sector of Ukraine: [monograph] / N. Sirenko. - Mykolaiv, 2010. - 416 p.

7. Innovative transformation of the agricultural sector [monograph] / [O. Shubravska, L. Moldovan, B. Paskhaver J. et al.] Ed. Dr. Sc. Sciences O. Shubravska; NAS of Ukraine, Institute of Economics. and prohnozuv. - K., 2012. - 496 p.

8. The Committee of Statistics of Ukraine [Electronic resource]. - Access: http://www.ukrstat.gov.ua 